れに反し，低照度に対しては比較的安定で， $0.05 \mathrm{~cd} / \mathrm{m}_{2}$ 以下で $\mathrm{S}_{1}$ は著明に增大するが，乙の時にもな㧍 $\Delta \mathrm{S}$ の 変化はきわめて小きい。

\section{〔産業心 理〕}

\section{1. 集中機能表現方法に関する研究}

高橋正幸，高桑栄松（北大・衛生）

学働に祭して，心的緊張の度合いは，作菜能率乙きう めて密接な関係有している。即ち心的緊張の度合いぶ 高い時は，注意の集中も容易であり，反忘も速やかであ る。乙の心的緊㖘历至は注意集中能ともいらべきもの在 適確に把握する目的で，1点孛とらえ，てれ学維持する （視覚と上肢および一定の姿勢維持の協調作業）作業を 行なわせ，ての集中維持機能を電気的に㩲記せしめる装 置を考案りや。

美験対象は，6事業所における徒業員中より，延 335 名を抽出し，各 1 日 2〜4回 1 分間，乙のテスト老試み

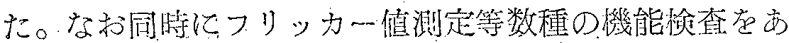
わせ行なった。

排記された曲線は，各個体に图有な波型を榙き（これ を原型と仮称）。乙れは生活または作業の焦行とともに变 化を示す（反型と仮称）。波型はをの特徽によって数 種に分類される。

原型：1）一定水準で概ね平坦な曲線を示すもの。

2) 大きなピーク一つを有するものと，ピークと谷学 备一つ拈くもの。

3) ピーク二つと一つの谷を示すものと，ピークおよ び谷各各二つを示すもも等である。

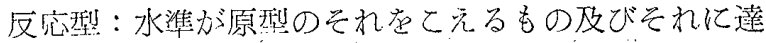
しないもの汸あり，さらにその中それぞれ型の変化が観 察される。

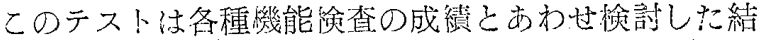

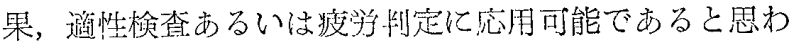
れる。

372. 再び座業織場におけるコーネル指数の応用につい $\tau$

菻师利彦（三蔆電㙨名古屋製作所） 租父江冕郎（名大・内科）

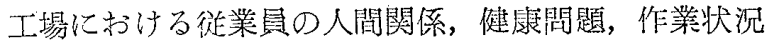
適性配䁂，精神状態を総括的に把握する目的で考案され たCornell medical Index を全從業䝿に实施し, 昭和
28年，第 1 回施行の成績（昭和29年本学会総会に発表） と比較し，量生管理面上における精神躈生，健康管理へ の二，三の知晃を得たので報告する。

全 196 項目よりなるアンケート形式によるもので，身 体, 疾病, 猊慣, 性格, 情緒, 精神等々のすべての精神 身体医学的要因を網羅した質問より棈成されている。

1. 調查人員 28 年 2996 名，34年 4586 名

2. 挀光数30以上の者について集計してみると，28年 $17.3 \%, 34$ 年 $10.3 \%$ であって，後者が約 $7 \%$ の減少党 認め，女子に就いて，10\%の減少岩認めた。

各訴えの内容について, 前回調查時と比較してみると ととに精神的項昌の訴え数に执いて，かなりの減少它認 わた。このととはなにか，社会環境条件や産業全般的な 帅態の変化汃背景となっているので法ないかと推定され る。

3. 筋肉学衝群においての訴えの率は 26〜30 才に最

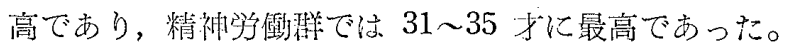

4. 各項質問中，眼と耳，心㖪㿼管系，消化器，符肉

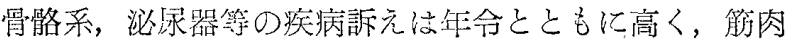

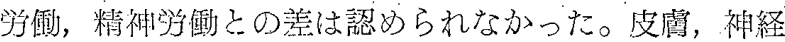

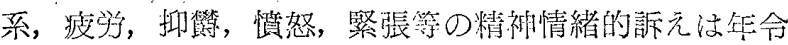
とともに減少觉めた。

5. 有害作業中，粉䵇，ベンゾール，踽畜作業者につ

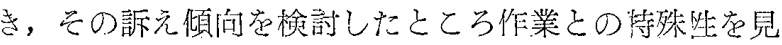
出すととができた。

6. 職場別に榆討した場合，訴え数の高濕な職場はな んらかの精神医学的問題の存在が若えられ，作業形態や 人間関係における間題点が認好られた。

7. 災管頻発者，不槼則久勤者等のグループについて

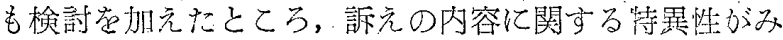
られた。

\section{3. 健康管理と C. M.I.}

川渏治，森隆（旭硝子）

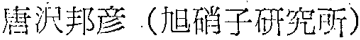

学德者の健康管理の目的は，心身同一來として煡全で みずから最適度の最高能力老発揮して，学働するてとの

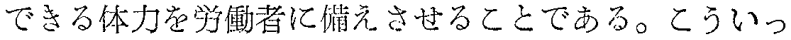
た立場汃らみると，現在，多くの企業で行なわれている 健豦管理の方式に活再考の余地が少なくない。

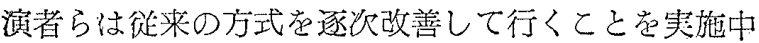
であるが，その一環として，C.M.I. 調查を行なって， 有用性を確め得たので，䒴千の結果芷報告する。

1. 演者等の勤陊する工場従業貣について調査を行な 